\title{
Colonial Neighbours in an Era of Change
} Portugal and the Netherlands in Timor, 1945-1949

\author{
Steven Farram
}

School of Creative Arts and Humanities, Charles Darwin University steven.farram@cdu.edu.au

\begin{abstract}
This article describes conditions in Timor in 1945-1949. Many problems facing the Portuguese and Dutch administrations revolved around Timorese activities such as unauthorized immigration, localized warfare, and livestock theft. Australia's ambitions in the region and the support granted to independence movements by other nations created new challenges. The latter was particularly true for the Dutch, who had to deal with the influence of the Indonesian Republic, whose success eventually led to their departure. Portugal feared a similar fate, but it is explained how local conditions and a deal between Portugal and the Allies during the Second World War allowed it to retain its colonial possessions virtually free of criticism. Most histories of Timor concentrate on either the east or the west part of the island. This article, based mainly on primary sources, details the post-war situation in Timor for all the major groups concerned: the Portuguese, the Dutch, and the Timorese.
\end{abstract}

\section{Keywords}

Australia - the Netherlands - Portugal - Timor - decolonization - Second World War

\section{Introduction}

This article examines conditions in post-Second World War Timor, including developments that saw one of the two colonial powers leaving the island only a few years after the war's end. Portugal and the Netherlands had been neighbours in the Timor region for over 300 years. The east-west division of Timor dates from 1769, when the Portuguese left Oecussi (Oecusse) to establish their capital at Dili. After much rivalry the two powers negotiated their Timor posses-

(C) STEVEN FARRAM, 2017 | DOI: 10.1163/22134379-17301001

This is an open access article distributed under the terms of the Creative Commons 
sions through a series of treaties, finally settling the matter in 1914. One result was that the homelands of Timor's major ethnic groups were divided by international borders. Thus the Tetun, the major group in East Timor, now live on both sides of the central border, as do the Bunak and Kemak; and the Atoni, the major group in West Timor, are also dominant in Oecussi (where they are called the Vaiqueno). Many Timorese ignored the colonial borders where they interfered with family obligations, trade, or feuds with neighbouring groups. Following partition, Dutch-Portuguese disagreements centred on border disputes, localized warfare, unauthorized immigration, and livestock theft-all problems concerning the Timorese. Smuggling also involved Europeans and Chinese. After the Second World War, this pattern continued, and these matters are examined in this article. Post-war developments are also considered, such as Australia's attempts to exert influence in Timor; the colonial powers' different views on how to engage their subject populations; treatment of war criminals; and competition to establish an international airport. The article concludes with some discussion of Portuguese-Dutch collaboration and mutual concerns about the growing influence of the Indonesian Republic, whose success eventually led to the Dutch departure. Local conditions and promises made to Portugal by the United States of America (USA) and the United Kingdom (UK) during the war allowed the Portuguese to retain control of their half of Timor long after all the other colonial powers had left the region.

Most writing on Timor concentrates on either the east or the west, but often includes information on the early colonial manoeuvring that led to partition (for example, Gunn 1999; Shepherd 2014). Meanwhile, some anthropologists, such as Friedberg (1980) and Kehi and Palmer (2012), have looked at groups living on both sides of the borders, while historians of early colonial Timor, like Boxer (1947) and Hägerdal (2012), have looked at the island as a whole. A rare case is the recent work by Kammen (2016), which gives a detailed account of a district that was once identified with the Dutch and later with the Portuguese. The present study is different to others in that it examines in detail the postwar situation in Timor for all the major groups concerned: the Portuguese, the Dutch, and the Timorese. This previously untold story is related using a variety of secondary and primary sources, including Dutch and Australian archives, and Portuguese official publications from the period.

\section{Australia: The Third Neighbour}

Following the Japanese capitulation in August 1945, Australia was responsible for occupying the eastern Indonesian archipelago on behalf of the Allies. 
The Dutch and the Portuguese expected to accept the Japanese surrender in their respective halves of Timor, but Australia thought otherwise. In correspondence with the UK, Australia declared that Portugal had no right to be involved, as it had not been at war with Japan and had been merely 'an acquiescent spectator in the Pacific War'. According to Australia, the Portuguese were 'unfit to be entrusted with defence of territory so important to the security of this area'. Australia proposed that after accepting the Japanese surrender, its forces should remain in Portuguese Timor until Portugal and Australia concluded the defence and economic arrangements for the territory first proposed in 1943. The UK countered that such arrangements should be concluded after the re-establishment of Portuguese authority, and that any Australian occupation would have a negative effect on the UK, which wished to maintain good relations with Portugal to ensure continued use of military bases on the Azores Islands. Australia softened its tone, but suggested that Portuguese Timor could instead be placed under United Nations (UN) trusteeship. ${ }^{1}$ This would have required the consent of Portugal, which would have been unlikely to be forthcoming, and the idea was not pursued.

In this exchange Australia ignored that the breach of Portuguese neutrality caused by the Australian-Dutch occupation of Dili in December 1941 may have been responsible for the subsequent Japanese invasion. Australia also overlooked that as early as January 1945 the UK and the USA had agreed to Portugal's wish that Portuguese forces would participate in operations to expel the Japanese from Timor. Accordingly, the UK asked Australia to allow 4,00o Portuguese troops to receive training in Australia. ${ }^{2}$ Australia replied that it had too many other commitments to host the Portuguese as well. ${ }^{3}$ Thus, Portugal's failure to engage with the Japanese was not due to lack of will, as Australia suggested. The Japanese, meanwhile, realizing that their defeat was inevitable, believed that if an orderly transfer of authority was arranged Japanese troops could withdraw from Portuguese Timor without an Allied occupation taking place. The transfer of authority took place on 5 September 1945, but with no transport available there was no chance of a Japanese withdrawal. Portugal,

1 Commonwealth Government to Addison, Cablegram 256, Canberra, 28-8-1945; Addison to Commonwealth Government, Cablegram 344, London, 30-8-1945; Commonwealth Government to Addison, Cablegram 269, Canberra, 3-9-1945, in Hudson and May 1989:374-80, 391-3.

2 Cranborne to Commonwealth Government, Cablegram 72, London, 13-3-1945, in Hudson and May 1989:83-4.

3 Bruce to Curtin, Cablegram 72A, London, 11-6-1945; Commonwealth Government to Cranborne, Cablegrams 158 and 159, Canberra, 16-6-1945, in Hudson and May 1989:209-10, $215^{-6 .}$ 
however, let it be known it considered an Allied occupation completely unnecessary (Gunn 1999:231-2). By then, Australia knew that the Japanese had not established separate commands in the two halves of Timor, so only one surrender ceremony was necessary. This took place aboard an Australian warship in Koepang (Kupang) Bay on 11 September 1945, with the Dutch denied any major role, despite their activities against the Japanese throughout the war. ${ }^{4}$ This move was symptomatic of Australia's attempt to monopolize all credit for the Japanese defeat.

Australia remained determined to appear as the victor in Portuguese Timor also, and on 22 September 1945 an Australian mission arrived in Dili to inform Governor Manuel de Abreu Ferreira de Carvalho that the commander of the Australian forces, Brigadier Lewis G.H. Dyke, would be arriving the following day. The governor sought a postponement in order to repair his broken radio and receive instructions from his government, but was told that it would suit Dyke to finalize the removal of the Japanese from the territory immediately, although matters requiring confirmation of instructions could be settled later by the two governments. Ferreira de Carvalho agreed, but informed the Australians that the Japanese surrender would be purely military, as administrative control had already been surrendered to the Portuguese, and all posts had been re-occupied by Portuguese personnel since 19 September. The governor added that this re-occupation had been carried out without military support and that the colony was in 'absolute order' with the Timorese population 'peaceful, obedient and disciplined' (Carvalho 1947:459-66). Ferreira de Carvalho was making it clear that Australian assistance to re-occupy the colony was not required and that as soon as the Australians had dealt with the Japanese they could leave.

On 23 September, Dyke arrived in Dili to formally notify the governor of the surrender of Japanese forces on Timor. ${ }^{5}$ Discussions between Dyke and Ferreira de Carvalho were characterized by the latter as 'cordial and friendly', with the Australians making no attempt to impose their wishes without consent. On 24 September, Dyke and Ferreira de Carvalho signed a memorandum of understanding allowing Australian officers freedom of movement to effect the removal of the Japanese and any associated war materials; to release any Allied prisoners of war and internees; and to investigate Australian war graves. Dyke agreed that any personnel accompanying Australian officers would be unarmed. Australian-Portuguese cooperation in the matter of war crimes was

4 Report by Merton Woods, Australian War Memorial, Canberra (AWM), AWM54, 773/4/14.

5 Report by Forsyth, Extract, 1-10-1945, in Hudson and May 1989:470-2. 
the only issue referred to by the respective governments (Carvalho 1947:45966). At Dyke's suggestion, 6o Australian military personnel attended a public ceremony in Dili on 24 September in which Dyke and Ferreira de Carvalho made speeches acknowledging Australia's association with the liberation of Portuguese Timor. ${ }^{6}$ As discussed later, cooperation relating to war crimes never occurred, but the general tone of Ferreira de Carvalho's subsequent report was one of satisfaction in deterring the Australians from any inappropriate action while they were in his territory.

The Portuguese and the Dutch were wary of the Australians, and with good reason. War-time experience led some Australians to believe that the best way to protect Australia's north was to take control of Timor. The idea had been raised early in the war by a perhaps surprising source. In June 1943, the USA's president, Franklin Roosevelt, wrote to the U K's prime minister, Winston Churchill, about their negotiations with Portugal for the military use of the Azores, stating that ' $\mathrm{t}] \mathrm{he}$ thought has come to me that if any question arises in regard to Timor, Australia might be interested in purchasing it in the interest of the defense of the South West Pacific'. Churchill agreed, but reminded Roosevelt that as they had assured the Portuguese that they would support continued Portuguese sovereignty over all their colonies after the war, the Portuguese would 'probably resent any early suggestions concerning the disposal of Timor' (Tarling 2013:82).

In August 1945, an Australian representative asked the Portuguese ambassador in London how his government would respond to the suggestion of a 100-year lease of Portuguese Timor to Australia. The ambassador replied that Portugal could not relinquish sovereignty of any territory. ${ }^{7}$ There seems to have been no follow up to this approach, but on 26 January 1946, Australia's first consul to Portuguese Timor, Charles Eaton, arrived in Dili to keep an eye on Australia's security and business interests, although the latter were limited. West Timor had not been forgotten, however, and in April 1947, John Burton, secretary of Australia's Department of External Affairs, suggested to Dutch officials in Canberra that the Netherlands could diminish its large war debt by allowing Australia to administer West Timor. ${ }^{8}$ The following month, Eaton travelled to West Timor, partly to investigate ways in which Australia could gain a long-

6 Report by Forsyth, Extract, 1-10-1945, in Hudson and May 1989:470-2.

7 Commonwealth government representative, London, 27-8-1945, National Archives of Australia, Canberra (NAA Canberra), A5954, 564/6.

8 Tijdelijk zaakgelastigde te Canberra (De Ranitz) aan minister van buitenlandse zaken (Van Boetzelaer van Oosterhout), 24-4-1947, in Van der Wal 1979:369-71. 
term lease of the territory or parts of it, but his enquiries were unproductive. ${ }^{9}$ The fact was that the Dutch officials had been instructed not to enter into discussions on the matter.

Despite some officials' ambitions, Australia's post-war military presence in Timor was short-lived. In Portuguese Timor most members of the pre-war administration were still in the territory at the end of the war, and other Portuguese officials and troops were soon on the way to the colony from other Portuguese posts. Australia made certain that the Japanese surrender was made to the Australian military and not the Portuguese, but once that and other formalities had been satisfied, Australian forces left the territory. In West Timor it was agreed that the Australians would help the Dutch reestablish their administration, and for this purpose Dutch civil and military authorities accompanied the occupation force, but the Australian army handed over command to the Netherlands Indies forces in March 1946. Following the Australians' departure, Portuguese-Dutch relations returned to the pre-war routine, where the main disputes concerned the Timorese.

\section{Border Disputes and Livestock Theft}

Border disputes had been common in the early twentieth century, but decreased as the colonial powers consolidated their control. There seem to have been no major disputes concerning the central and Oecussi borders during the immediate post-war years, but the potential was there. In West Timor in the years 1945-1948 there were at least five serious district-level border disputes, three of which resulted in loss of life (Versluys 1949-1950:133). Meanwhile, livestock theft remained a perennial problem.

In March 1946, the controleur (administrative head of a division or subdivision) of the Dutch subdivision of Beloe (Belu), facing the central border, reported that trade had been hindered by the tense situation caused by cattle thefts organized from Portuguese territory..$^{10}$ Around a year later, the head of the Dutch administration, Resident C.W. Schuller, reported that 200 buffaloes had recently been stolen from Dutch territory by people from Portuguese

No. 63: Eaton, Consul, to Secretary, Department of External Affairs, 12-5-1947; Secretary, Department of External Affairs to Secretary, Department of Defence, 23-5-1947, NAA Canberra, A1838, TS400/1/9/1/1.

10 Politiek verslag van chief commanding officer Nica (De Rooy) betreffende Borneo en de Grote Oost, 16 febr.-1 maart 1946, in Van der Wal 1973:470-4. 
Timor. ${ }^{11}$ The Portuguese claimed that soldiers from the Dutch side had twice crossed the border to retrieve stolen buffaloes. The Dutch reported that this was not true, but that soldiers from the Portuguese side had been involved in the initial theft. ${ }^{12}$ The case petered out, but in February 1948 it was reported that around 100 head of cattle had been driven into Oecussi from Dutch Timor in October the previous year. According to the Dutch, the cattle were transported by sea to Dili and other places in Portuguese Timor. ${ }^{13}$ Then, in April 1948, it was reported that a chefe de posto (administrative head of a sub-district, or posto) in Portuguese territory was implicated in receiving stolen horses, but the case was unable to be proven. ${ }^{14}$

Despite suspicions that some officials may have been involved in livestock theft, it was not usually a source of friction between the European administrations, as it was considered normal, although regrettable, Timorese behaviour. However, a series of border crossings and killings in 1946 raised new concerns. The incidents involved a group of Portuguese Timorese who had resettled in the Kewar district in Dutch territory during the war. In January 1946, some of those people returned to their former homes to collect their possessions, but a fracas ensued in which 20 people were killed and a village burnt to the ground before the people from Kewar managed to flee back to Dutch territory. ${ }^{15}$ The Portuguese claimed that those people were livestock thieves who came into conflict with their neighbours, forcing them to seek refuge across the border. The Dutch were not so sure, but agreed it would be best if the people involved were moved further inland from the border. It was also agreed that at an appropriate time a reconciliation feast based on adat (customary law; known in Tetun as lisan) should be held. ${ }^{16}$ More important was the recognition that 'international complications' could have arisen if military border

11 No. IV: Verslag van den Resident van Timor en Onderhoorigheden over Februari 1947, Nationaal Archief, The Hague (NA), Algemene Secretarie 3259. Following a government programme, cattle began to outnumber buffaloes in much of Dutch Timor, but remained popular in many of the central districts throughout the 1940s; see Ormeling 1956:159-61.

12 No. III: Verslag van den Resident van Timor en Onderhoorigheden over de eerste helft van Februari 1947, 24-2-1947, NA, Algemene Secretarie 3259.

13 Politiek verslag. Residentie Timor en Onderhoorigheden. Maand: Januari/Maart 1948, $15^{-}$ 4-1948, NA, Algemene Secretarie 3260.

14 No. vir: Politiek verslag van de eerste helft van de maand April 1948. Residentie Timor en Onderhoorigheden, 27-5-1948, NA, Algemene Secretarie 326o.

15 Politiek verslag van chief commanding officer Nica (De Rooy) betreffende Borneo en de Grote Oost, 16 febr.-1 maart 1946, in Van der Wal 1973:470-4.

16 No. XVIII: Verslag van den Resident van Timor en Onderhoorigheden over October 1946, 4-11-1946, NA, Algemene Secretarie 3259. 
patrols had been drawn into the dispute. ${ }^{17}$ Therefore, the Dutch and Portuguese established a joint commission in October 1946 to investigate the incidents and agreed on several measures for maintaining order, including: both parties were to punish subjects who crossed the border with weapons; both parties were to prevent subjects from shooting across the border; both parties were to report monthly on the number of immigrants; and border patrols were to be carried out by police, not soldiers. ${ }^{18}$

The killings in this case had drawn the attention of the Europeans, but most incidents of livestock theft were never reported because the Timorese had little trust that the thieves would be prosecuted. In June 1948, Schuller noted that one had only to look at the old reports of any border district's official to find mention of the 'irreducible love' of the Timorese on both sides of the border for livestock theft. Old feuds, he said, were often the cause of such thefts and were not considered by the Timorese to be a crime, but something meritorious. The only way to bring an end to the notion that such crime was a sport, asserted Schuller, was for offenders on both sides to be heavily punished. Owners also needed to guard their herds. ${ }^{19}$ Meanwhile, providing sufficient numbers of police was a challenge for the Dutch and in 1948 in Beloe 167 cases of livestock theft were reported, as well as 24 other thefts, 45 murders, and other violations of the law. ${ }^{20}$ How many of the 1948 cases involved Portuguese Timorese is unclear, but in January 1949 it was reported that cross-border livestock theft remained common. In one dramatic case in September 1948, 34 Portuguese Timorese, who had several years earlier settled in Dutch territory, were carried off by a band of armed men together with livestock and household items. The Dutch sought information from the Portuguese, but by January 1949 none had been received. ${ }^{21}$ The matter received no further mention in the Dutch records.

\footnotetext{
17 No. XVII: Politiek verslag van den Resident van Timor en Onderhoorigheden over de eerste helft van October 1946, NA, Algemene Secretarie 3259.

18 No. XVIII: Verslag van den Resident van Timor en Onderhoorigheden over October 1946, 4-11-1946, NA, Algemene Secretarie 3259.

19 Politiek verslag. Residentie Timor en Onderhoorigheden. Maand: April/Juni 1948, 18-61948, NA, Algemene Secretarie 3260.

20 No. v: Politiek verslag van de Residentie Timor Archipel over de maand Maart 1949, 25-41949, NA, Algemene Secretarie 3260.

21 Politiek verslag. Residentie Timor en Onderhoorigheden. Tijdvak: Juli t/m Januari 1949, 27-1-1949, NA, Algemene Secretarie 326o.
} 


\section{Smuggling}

There were many opportunities for smuggling on Timor, with two international land borders and shipping connections between the two halves of the island. The Dutch considered smuggling to be 'rampant', although it operated in both directions, with the smuggling of coffee to the Dutch port of Atapoepoe (Atapupu) having been a problem for the Portuguese since the nineteenth century (Kammen 2016:64-6). The Dutch assistent resident A.J. van Es reported in April 1948 that smugglers were apprehended on the boat Bintang Timoer, although it was not stated whether they were smuggling goods into Portuguese or Dutch Timor. In another case the Chinese Jap Son Soe of Atamboea (Atambua) in West Timor was declared to have smuggled unidentified goods into Portuguese Timor by boat. Jap Son Soe was also under investigation due to a report that he bought a tommy gun with 500 bullets from the Javanese bugler Jasadihrama in 1942. Van Es noted that Manbora on the Lois River (on the Timor Leste north coast, relatively close to the central border) was a special place for weapons smuggling. ${ }^{22}$ The weapons may have been Japanese or Allied guns left over from the war. Rifles had always been popular on Timor for the hunt, for ceremonial purposes, and as symbols of manhood, so any sign of weapons trade was not necessarily a pointer to imminent armed rebellion. Nevertheless, both the Dutch and the Portuguese had attempted to limit Timorese access to firearms from the early decades of the twentieth century, mainly to prevent such a possibility.

In June 1948, Schuller reported that the Netherlands Indies customs service could not cover the whole of West Timor and concentrated its efforts at Atapoepoe near the central border. Apart from smuggling, checks at this port revealed other irregularities. For example, Portuguese subjects travelling by ship from Dili to Dutch Timor were required to obtain an approval card from Makassar in Celebes (Sulawesi), which was unreasonable and unworkable. Schuller cited the case of a Chinese Portuguese subject discovered at Atapoepoe with a valid passport, but not the other required documentation. In his passport, however, was a note from the administrador (administrative head of a district) of Dili saying the man only wished to visit family in Koepang. It seems this was a common practice. It also frequently occurred that people travelling from Oecussi to Dili by road did not bother to alert the Dutch authorities. If discovered, their vehicles were searched thoroughly. The Dutch were particularly concerned about

22 No. VII: Politiek verslag van de eerste helft van de maand April 1948. Residentie Timor en Onderhoorigheden, 27-5-1948, NA, Algemene Secretarie 3260. 
the black market in foreign currencies. Schuller clashed over this matter with Ferreira de Carvalho's replacement, Óscar Freire de Vasconcelos Ruas, with the latter claiming that the 1946 Netherlands-Portuguese monetary treaty did not apply to his territory. Schuller sought assurances that it did, and then declared that passengers who boarded Dutch ships at Dili would be subject to the regulations. ${ }^{23}$ One issue about which there was some uncertainty was barter trade carried out across the central border. The Dutch resident sought clarification from the Bureau Uitvoerzaken (Exports Office) and was advised that there was no objection to such trade, provided it was restricted to local products and not imported goods that had required expenditure of foreign exchange on the part of the Dutch. This ruling was welcome, because while the trade was of little importance to the overall economy, it was of great importance to local traders. $^{24}$

\section{Unauthorized Immigration}

Unauthorized immigration was a long-standing problem. In June 1948, the Dutch reported that Portuguese Timorese sought refuge in Dutch territory for three main reasons: to escape high taxation; to avoid corvée (forced labour); and to avoid punishment for having committed a crime. In some border districts up to half the population was considered to be made up of ex-immigrants, many of old origin, but with newcomers arriving regularly. Following an investigation, it was found that in the district Lakekun alone 47 people had arrived in the first three months of the year. Portuguese officials sent letters weekly to their Dutch counterparts seeking extradition of such fugitives. These letters usually contained details of the emigrants' crimes and the locations to which it was believed they had fled. Normally, formal extradition procedures were dispensed with and the people concerned were simply collected by the police and returned to the other side. The Portuguese performed the same service for the Dutch. The Dutch, however, would not return people who they believed had settled in their territory only to avoid high taxes and heavy labour. ${ }^{25}$

23 Politiek verslag. Residentie Timor en Onderhoorigheden. Maand: April/Juni 1948, 18-61948, NA, Algemene Secretarie 3260.

24 Politiek verslag. Residentie Timor en Onderhoorigheden. Tijdvak: Juli t/m Januari 1949, 27-1-1949, NA, Algemene Secretarie 3260.

25 Politiek verslag. Residentie Timor en Onderhoorigheden. Maand: April/Juni 1948, 18-61948, NA, Algemene Secretarie 3260. 
Compulsory labour had been a feature of traditional governance in much of the Indonesian archipelago long before the Europeans arrived. Gradually, such labour came to be performed for the benefit of the Dutch and Portuguese administrations, usually organized by traditional rulers. In the Netherlands Indies, compulsory labour was replaced by a variety of taxes (Cribb 1992:1856). However, the Dutch continued to rely on corvée in West Timor and surrounding islands long after it had been phased out elsewhere. In Portuguese Timor forced labour was also organized by traditional rulers for the benefit of the state; and under the Japanese, Timorese on both sides of the border were forced to work on roads, growing food for the occupying troops and other projects. Corvée was not continued in West Timor post-war, but in Portuguese Timor it was. It may have even increased due to the reconstruction of roads, buildings, and port facilities in the devastated territory. Each suco (village) provided workers for one month each year, leading to a decline in agricultural production. A member of the Australian War Graves Commission who was in Portuguese Timor in 1947 described the system as 'brutal', with workers labouring 'under the whip [...] from dawn to dusk' (Taylor 1991:14). Forced labour for the benefit of the state was maintained until the last days of Portuguese rule. Labour was also required for the coffee, rubber, and cocoa plantations that employed thousands of Portuguese Timorese, and 'Agricultural Correction Centers' used prison labour under slave-like conditions until the 196os. Alongside these labour demands there was also an oppressive taxation system (Shepherd and McWilliam 2013:338-9). The Australian consul, Eaton, reported in December 1946 that the yearly head tax payable by the Portuguese Timorese had been increased from 6 patacas to 16 patacas. The increase, said Eaton, had caused 'shock and grumblings', although there was no organized opposition. ${ }^{26}$

It was different on the Dutch side of the border. Eaton reported in May 1947 that 'the natives of Dutch Timor' were required to pay a head tax of four guilders ( $f 4.00)$ a year, which was an increase of $f 1.50$ from the pre-war rate; nevertheless, it was a much smaller percentage increase than that experienced across the border. If they failed to pay the tax, the Dutch Timorese were required to

26 No. 9: Eaton, Consul, to Chiffley [sic], Acting Minister of State for External Affairs, 27-81946, NAA Canberra, A5954, 2269/4; No. 16: Eaton, Consul, to Evatt. 4-12-1946, NAA Canberra, A1838, 377/1/3 Part 1. British officials who visited Portuguese Timor in 1937 and 1941 reported a basic head tax of 6 patacas, with those in private employment paying 11 or 16 patacas. There were very few in the latter category. Report by E.T. Lambert. December 1937, NAA Canberra, A1838, 376/1/1; Report on Portuguese Timor by C.H. Archer. May 1941, NAA Canberra, A981, тIм Р 9. 
work for ten days; that is, labour was required in lieu of the tax, not in addition to it, as in Portuguese Timor. ${ }^{27}$ Also, the tax in Dutch Timor was far lower than in Portuguese Timor: with an official exchange rate of $f 0.67$ for 1 pataca, ${ }^{28}$ the Portuguese tax was nearly $f 11.00$ compared to the Dutch tax of $f$ 4.0o. Despite these differences, Eaton suggested there was greater dissatisfaction on the Dutch side of the border, claiming that ' $\mathrm{t}$ ] he natives seem to be reserved toward the Dutch in comparison with an outward show of respectfulness of the natives of Portuguese Timor towards the Portuguese. ${ }^{29}$ The reason for that may have been a greater political awareness among some Dutch Timorese due to knowledge of the Indonesian independence movement (discussed later). Nevertheless, the Portuguese did not have everything their own way. During a tour of the Hatolia, Bobonaro, Marobo, and Balibo districts in December 1946, Eaton witnessed collection of the head tax firsthand. The substantial increase had caused considerable discontent and while $50 \%$ of the people had paid, it proved difficult collecting the rest. Some people had gone bush to avoid payment. In some districts, those who remained and had not paid the tax were said to be 'bad men' who had cooperated with the Japanese during the war. Eaton noted that such people were subject to corporal punishment. ${ }^{30}$

Experiences such as those described by Eaton may have encouraged some Portuguese Timorese to cross the border. Meanwhile, another reason for border-crossings was family matters, as people regularly crossed the border simply to reside with relations on the other side. This could make fugitive criminals or tax avoiders difficult to find, as they were hidden by relatives until interest in them died down.

Meanwhile, escaped prisoners who crossed the border were usually dealt with in the same fashion as fugitive criminals; that is, returned on request with minimal formalities. ${ }^{31}$ In September 1947, it was reported that four Portuguese Timorese political prisoners who had escaped from the prison settlement on Ataúro Island were found working as labourers on Alor Island. Schuller's assessment was that the men were merely 'undesirable elements'.

27 No. 63: Eaton, Consul, to Secretary, Department of External Affairs, 12-5-1947, NAA Canberra, A1838, TS400/1/9/1/1.

28 Politiek verslag. Residentie Timor en Onderhoorigheden. Maand: April/Juni 1948, 18-61948, NA, Algemene Secretarie 3260.

29 No. 63: Eaton, Consul, to Secretary, Department of External Affairs, 12-5-1947, NAA Canberra, A1838, TS40o/1/9/1/1.

30 No. 17: Eaton, Consul, to Evatt. 18-12-1946, NAA Canberra, A1838, 377/1/3 Part 1.

31 Politiek verslag. Residentie Timor en Onderhoorigheden. Maand: April/Juni 1948, 18-61948, NA, Algemene Secretarie 3260. 
He had not received an extradition request, but he was assured that the men would rather be killed than be returned to the 'Timorese Cayenne'.32 Schuller's comparison of Ataúro with the notorious French penal colony suggests he did not approve of the Portuguese prison island, yet the Dutch had a long history of using islands and other remote locations in the Indies as places of detention for criminals and political offenders. Also, it was in the context of these men from Ataúro that Schuller expressed his hope that instead of referring such cases to the governments in Batavia and Lisbon, the old practice of simply returning escaped prisoners to the other side should be continued.

\section{Prosecution of War Criminals and Collaborators}

During Brigadier Dyke's visit to Portuguese Timor in September 1946, and shortly afterwards, Australian investigators collected testimonies concerning atrocities committed by the Japanese against local Timorese, Chinese, and Portuguese, but no action was taken. It was similar in West Timor: information was collected about collaborators with the Japanese, and Japanese war crimes committed against Timorese and Chinese, but the Australians left these matters to be dealt with by the Dutch. The few war crimes charges brought against Japanese by the Australians concerned maltreatment of Australian prisoners of war and the killing of two Allied servicemen: Australian Corporal J.H. Armstrong and the English gunner known simply as Martin. The cases were heard during the only war crimes trials held in Australia, convened in Darwin in March-April 1946. A number of the Japanese accused were acquitted and the remainder received light sentences, except for Lieutenant Colonel Yutani Yujiro, who was found guilty of ordering the executions of Armstrong and Martin and was executed by firing squad in August 1946 at Rabaul in the Territory of Papua and New Guinea (Gill 1995:100).

Following the Australian withdrawal, the Dutch continued investigating war crimes and cases of collaboration with the enemy. The Temporaire Krijgsraad (Temporary Military Court) in Koepang proved more willing to establish guilt than its Australian equivalent in Darwin. However, although the court had existed since at least June 1946, with the arrival of its president, Dr Damen, and

32 Politiek verslag. Residentie Timor en Onderhoorigheden. Maand: Augustus 1947, 5-9-1947; Politiek verslag. Residentie Timor en Onderhoorigheden. Maand: September 1947, NA, Algemene Secretarie 3259 . 
other officials, ${ }^{33}$ the collecting of evidence and the arranging of interpreters and other matters caused lengthy delays. ${ }^{34}$ In February 1947, there were 127 Japanese awaiting trials in Koepang, but only nine cases were ready to proceed. ${ }^{35}$ In June 1947, more Japanese accused arrived from Java, but in August 1947, five Japanese prisoners working at the Penfoei (Penfui) airfield decided to escape. One was recaptured soon after and three others were shot dead while on the run at Bonmoeti, in Dutch territory south of Oecussi. The fifth man, Sergeant Major Yoshimitu Sato, was caught by 'natives' after being shipwrecked in a stolen boat at Maubara in Portuguese Timor. Miserable and desperate, Sato unsuccessfully attempted suicide in the Dili prison by slashing his wrists and hanging himself. ${ }^{36} \mathrm{He}$ was flown back to Koepang by the Portuguese military. Resident Schuller regretted that 'an unpleasant and painful spectacle' was witnessed by the Portuguese at the time of the handover as the handcuffed prisoner was given 'completely superfluous punches and blows' by the Dutch military police. ${ }^{37}$ Sato's fate is unclear although there were claims he had been involved in deaths around Dili during the war and that he had killed a guard in escaping from Koepang. ${ }^{38}$ Meanwhile, the trials of Japanese in Koepang proceeded, with two cases settled around the time of Sato's return, resulting in Ando Shuji being sentenced to 12 years' imprisonment and Murakami Shogo being sentenced to death. The execution was carried out on 3 September $1947 \cdot{ }^{39}$

33 No. XI: Verslag van den Conica Timor over de tweede helft van Juni 1946, 30-6-1946, NA, Algemene Secretarie 3259 .

34 No. XII: Politiek verslag van den Resident van Timor en Onderhoorigheden over de maand Juni 1947, 1-7-1947; No. XXII: Politiek verslag van den Resident van Timor en Onderhoorigheden over de tweede helft van de maand December 1946, 5-1-1947; No. II: Verslag van den Resident van Timor en Onderhoorigheden over de maand Januari 1947, 6-2-1947, NA, Algemene Secretarie 3259.

35 No. Iv: Verslag van den Resident van Timor en Onderhoorigheden over Februari 1947, NA, Algemene Secretarie 3259 .

36 Politiek verslag. Residentie Timor en Onderhoorigheden. Maand: Augustus 1947, 5-9-1947; No. XVII: Politiek verslag van den Resident van Timor en Onderhoorigheden over de 1e helft van de maand September 1947, 24-9-1947; No. XVIII: Politiek verslag van den Resident van Timor en Onderhoorigheden over de maand September 1947, 4-10-1947, NA, Algemene Secretarie 3259 .

37 Politiek verslag. Residentie Timor en Onderhoorigheden. Maand: September 1947, NA, Algemene Secretarie 3259 .

38 No. 7/47: Pigram, A/Consular Clerk to Chifley, A/Minister of State for External Affairs, 9-101947, NAA Canberra, A1838, 377/1/3 Part 2.

39 No. XVIII: Politiek verslag van den Resident van Timor en Onderhoorigheden over de maand September 1947, 4-10-1947, NA, Algemene Secretarie 3259. 
At least three Japanese were sentenced to death in 1948. Others received sentences ranging from 5 to 20 years imprisonment. There was also at least one acquittal. ${ }^{40}$

On one day at the Koepang war crimes trials, in October 1946, the death sentence was handed out twice, in two notorious cases. One of these was that of Pius Rasi Wangge, the zelfbestuurder (traditional ruler recognized by the Dutch, also known as raja) of the principality of Lio on Flores Island, who was found guilty of inciting rebellion and collaboration (opstand en collaboratie) in May 1942. Wangge unsuccessfully appealed the sentence and was executed in April $1947 \cdot{ }^{41}$ To execute a raja was no small thing, as traditional rulers such as Wangge were essential to the smooth running of the colonial state, serving as intermediaries between the government and the people, whose lives were still largely regulated according to adat. A raja was a person treated with great respect, yet the death sentence delivered to Wangge was said to have been reassuring to the people in Flores. ${ }^{42}$

The other collaborator sentenced to death in October 1946 was Roefoes Takoe, a Timorese agent of the Japanese military police, the Kempeitai. ${ }^{43}$ Takoe was implicated in the deaths of two Australian prisoners of war, Lance Sergeant Jack West and Lieutenant Bill Fitzallen, who had escaped from the Koepang prison camp in March 1942. The Australians were helped by several people, but Takoe revealed their hiding place to the Japanese, for which he received 25 guilders. ${ }^{44}$ West and Fitzallen were executed without trial sometime later in 1942, while their helpers were tortured and kept in jail for months, but the Japanese involved were never tried and the case was dropped due to insufficient evidence. ${ }^{45}$ However, several people were willing to testify against Takoe

40 No. IV: Politiek economisch verslag over de maand Februari 1948, 23-3-1948; No. VIII: Politiek economisch verslag over de maand April 1948. Residentie Timor en Onderhoorigheden, 31-5-1948; Lijst van den op 27sten Augustus 1948 per post aan Z.E. den Luit. Gouv.Generaal van Ned. Indie, verzonden dienststukken, NA, Algemene Secretarie 3260.

41 No. XvirI: Verslag van den Resident van Timor en Onderhoorigheden over October 1946, 411-1946; No. VIII: Verslag van den Resident van Timor en Onderhoorigheden over de maand April 1947, 3-5-1947, NA, Algemene Secretarie 3259.

42 No. XVIII: Verslag van den Resident van Timor en Onderhoorigheden over October 1946, 4-11-1946, NA, Algemene Secretarie 3259.

43 No. XVIII: Verslag van den Resident van Timor en Onderhoorigheden over October 1946, 4-11-1946, NA, Algemene Secretarie 3259.

44 E.F. Tokoh, Appx D: Copy of statement by Ketsia Feoh, National Archives of Australia, Melbourne (NAA Melbourne), MP742/1: 336/1/973.

45 Several witnesses stated the men were killed in October, others in June, or sometime in between. For examples see Report on the torture and fate of Lt. Fitzallen and L/Sgt 
for his actions in a number of cases. At his trial it was stated that Takoe had caused the deaths of many of his countrymen and that he would be cursed as the worst criminal and traitor that Timor had produced in living memory. Takoe was sentenced to death; in a verdict designed to appeal to Timorese Christian feelings, he was portrayed as having surpassed Judas Iscariot in his vileness and baseness of character. Takoe, it was explained, was content to betray the Australian escapees for only 25 pieces of silver, whereas Judas had received 30 pieces for his own act of betrayal. ${ }^{46}$ Reported to have been hated fiercely in Koepang, Takoe was executed on 6 February $1947 .^{47}$

On 6 March 1947, TaEl TaEk, 'the notorious war criminal from Atamboea', was also sentenced to death in Koepang, ${ }^{48}$ and in January 1948 a certain Balitoni was sentenced to 20 years in prison. ${ }^{49}$ On 15 May 1948, the 'long-sought-for criminal and collaborator', Elias Balo, who had been arrested in Portuguese Timor, was handed over to Dutch authorities. Throughout 1948, trials continued in Koepang and other collaborators were found guilty, receiving sentences ranging from a few months to eight years. ${ }^{50}$

In Portuguese Timor, Governor Ferreira de Carvalho issued a decree on 10 October 1945 naming 27 individuals who displayed great bravery, dedication to duty, and patriotism in guarding Portuguese interests during the Japanese occupation. These actions included organizing resistance to the 'native revolts' (revoltas dos indígenas) that occurred in the Covalima district and Maubisse sub-district in 1942, and helping with food supplies for Portuguese detained by the Japanese at Liquiçá from 1943. These matters are discussed further below. The people named by Ferreira de Carvalho were all Portuguese, other Europeans, or assimilados, that is, 'natives' who had achieved a level of civilization

West, 13-11-1946; No. 2248/C10/5: Murder of Fitzallen and West-June 1942, 13-2-1948, NAA Melbourne, MP742/1: 336/1/973.

46 Verdict in the name of H.M. the Queen: Rufus Takoe. Certified true translation. Singapore, 10-2-1947, NAA Melbourne, MP742/1: 336/1/973.

47 No. XVIII: Verslag van den Resident van Timor en Onderhoorigheden over October 1946, 4-11-1946; No. IV: Verslag van den Resident van Timor en Onderhoorigheden over Februari 1947, NA, Algemene Secretarie 3259.

48 No. vi: Politiek economisch verslag over de maand Maart 1948. 28-4-1948, NA, Algemene Secretarie 3259 .

49 No. II: Politiek economisch verslag over de maand Januari 1948, 15-3-1948, NA, Algemene Secretarie 3260.

50 No. viII: Politiek economisch verslag over de maand April 1948. Residentie Timor en Onderhoorigheden, 31-5-1948; No. x: Politiek economisch verslag over de maand Mei 1948. Residentie Timor en Onderhoorigheden. 6-7-1948, NA, Algemene Secretarie 3260. 
approximate to that of Europeans. ${ }^{51}$ In November 1945, the governor issued another decree acknowledging that many 'natives' had made sacrifices during the war because of their loyalty to the Portuguese flag. ${ }^{52}$ Ferreira de Carvalho also released for publication the text of a speech made by the régulo (Portuguese title for a traditional ruler, also known as liurai) of Viqueque at a ceremony marking the arrival of Portuguese relief forces on 29 September 1945. The Portuguese were surely gratified to hear the régulo (not named in the document) express his joy at the re-establishment of the Portuguese administration. ${ }^{53}$ In a 1947 report Ferreira de Carvalho listed the names of some 70 more Timorese who had shown great loyalty to the Portuguese during the occupation. The group included several liurai and lesser officials, but also many ordinary people. Several had died as a result of their resistance to the Japanese (Carvalho 1947:492-8).

During the first year after the resumption of Portuguese rule more information emerged about Timorese who had remained 'loyal' during the war. Often this meant they had protected Portuguese fleeing from 'disloyal' locals who had received arms from the Japanese, or the Japanese-backed 'black columns' (colunas negras) of Dutch Timorese, brought in from across the border. Because of their actions these Timorese suffered ill-treatment at the hands of the Japanese and often lost all their possessions. A list of around 40 such individuals was published in the government gazette in early 1947, where it was also announced that out of gratitude the Portuguese government would exempt them from the 'indigenous tax' for five years. Among those named were the widow and children of Aleixo Corte Real, the régulo of Suro, who along with his followers was killed by Japanese-led forces for his resistance in May $1943 \cdot{ }^{54}$ In the following two years, a further 110 or so 'loyal' Timorese were also rewarded with a tax emption for their pro-Portuguese actions during the war. ${ }^{55}$

$5^{1} \quad$ The group included army officers, civil servants, the director of a Portuguese-owned plantation, a missionary, and six departados (political exiles). See Portaria no. 1:137-A, 10 October 1945, in Carvalho 1947:484-9. An extra name was added to the list on 21 November 1945 (Carvalho 1947:489-90).

$5^{2} \quad$ Portaria no. 1:143, 21 November 1945, in Bretes 1989:122-3.

53 Discurso do régulo de Viqueque, em 29 Setembro de 1945, a chegeda das tropas expeditionárias a Díli, in Bretes 1989:124.

54 'Portaria no. 1:197', Boletim Oficial da Colónia de Timor 15:126-7, 12-4-1947.

55 'Portaria no. 1:375', Boletim Oficial da Colónia de Timor 36:335-6, 5-9-1948; 'Portaria', Boletim Oficial da Colónia de Timor, Suplemento 36:305, 5-9-1949. Although some earlier examples are mentioned below, this seems to be the last war-related notice to appear in the Boletim for the period examined, which was from the first post-war issue of 26-10-1946 to 28-121949 . 
However, there were also Portuguese Timorese and other Portuguese subjects who could have been labelled 'collaborators'. In August 1942, a rebellion against the Portuguese broke out in Maubisse and Ferreira de Carvalho complained in October 1942 of 'constant native uprisings' in various parts of the territory. These actions were more anti-Portuguese than pro-Japanese, but served Japanese purposes nevertheless (Gunn 1999:225). In many cases the Japanese had been directly involved in instigating the killings of Portuguese officials and civilians. One of the earliest examples occurred in late September-early October 1942, when the Portuguese military commander, Captain Freire da Costa, his wife, and several officials were massacred at Aileu. Japanese-instigated killings also occurred at Ermera. On 15 November 1942, the Portuguese administrador of Lautem, Manuel de Barros, his wife, and three Portuguese civilians were killed. At Aileu the Timorese involved were said to have been mainly from across the border, but at Lautem they were locals (Chamberlain 2005:34). By 1943, most Portuguese were being held in detention by the Japanese for their own 'protection' at Liquiçá and Maubara, where some Timorese were later employed as guards. Meanwhile, some members of the Arab community were reported to have been appointed chefe de posto or to have worked for the Kempeitai (Gunn 1999:226). The Dili commander of the Kempeitai, Kato Kazusada, accused of causing the suffering and deaths of many Portuguese at Liquiçá, was under arrest in Makassar in Dutch territory in 1947. With the agreement of the Netherlands Indies attorney-general, Resident Schuller acted as go-between in early 1948 to bring the 'war criminal' to Dili to stand trial. ${ }^{56}$ As Portugal had technically never been at war with Japan, he was presumably not charged as a war criminal; whatever the nature of his trial, the outcome for Kato Kazusada is presently unclear.

In May 1946, the Australian consul at Dili, Eaton, reported that '250 natives who collaborated with the Japanese [had] been deported to Kambing Island' (Ataúro). ${ }^{57}$ In January 1949, Resident A. Verhoef (who replaced Schuller in August 1948) also reported that 'collaborators' were being held on Ataúro.58 In fact it seems that people detained on the island had been charged with a range of crimes. Alfredo Pires, son of a colonial official and a Timorese mother, joined the Portuguese colonial administration after the Second World

56 Politiek verslag. Residentie Timor en Onderhoorigheden. Maand: October/November 1947, 15-12-1947, NA, Algemene Secretarie 3259; Politiek verslag. Residentie Timor en Onderhoorigheden. Maand: Januari/Maart 1948, 15-4-1948, NA, Algemene Secretarie 3260. No. 1: Eaton, Consul, 5-5-1946, NAA Canberra, A1838, 377/1/3 Part 1.

58 Politiek verslag. Residentie Timor en Onderhoorigheden. Tijdvak: Juli t/m Januari 1949, 27-1-1949, NA, Algemene Secretarie 326o. 
War. Pires recalled doing paperwork in Viqueque relating to people accused of crimes during the war. Pires said that if there was evidence that people had committed crimes because they were ordered to do so by the Japanese, they received light sentences. It is likely that some people were falsely accused by opportunists hoping to settle old scores, as Pires recounted that in one case in which go people were accused, only 20 were convicted. Many of the cases involved stealing and revenge killings, rather than collaboration with the Japanese, but Pires argued that the Japanese allowed collaborators to commit crimes in order 'to create fear'. He gave as an example a man accused as late as 1961 for killing an old woman during the war in order to steal her gold; he was allowed to get away with it at the time because he was helping the Japanese (Turner 1992:57, 66-7).

In early 1954, the chief justice of Portuguese Timor informed the Australian consul at Dili, F.J.A. 'John' Whittaker, that about 1,00o collaborators had been tried and sentenced to varying terms of imprisonment on Ataúro, while about 100 people were still awaiting trial. The slow progress was due to cases only being heard when other legal business was not too pressing. Most of those tried had been involved in the Aileu, Ermera, and Lautem massacres. They were all Timorese, with the exception of one 'Portuguese half-caste', who received a tenyear sentence for instigating Timorese collaboration in the Lautem area. The chief justice thought that some collaborators would have escaped across the border at the end of the war. ${ }^{59}$ Meanwhile, some people accused of collaboration were dealt with without trial. On 20 September 1947, Governor Ruas issued a decree declaring it had been proven in 'administrative proceedings' (processo administrativo) that four Chinese subjects—Lay Sui Fit (known as Atxit), Chung Hai Tsing (Ha Hoi), Iap Iau Leong (Iap Anhi), and Iap Assi (Assi Metan) - had acted against the Portuguese in collaboration with foreign forces that had occupied the colony. The nature of the collaboration was not stated, but the four were expelled from Portuguese Timor for a period of five years. ${ }^{60}$ In another case, in April 1949, Ruas decreed that Lieutenant Colonel Sebastião de Carvalho be stripped of his military title and be removed from all official positions, with the loss of any associated rights, privileges, or honours. Carvalho, it was explained, had been appointed régulo of Manatuto by the Japanese during the war. Carvalho was not accused of any criminal offence, but by collaborating with the Japanese he was said to have shown hostility towards the Portuguese. ${ }^{61}$

\footnotetext{
59 No. 3: Memorandum for the Secretary, Department of External Affairs. 8-2-1954, NAA Canberra, A1838, 3038/7/1 Part 1.

6o 'Portaria no. 1:285', Boletim Oficial da Colónia de Timor 38:343, 20-9-1947.

61 'Portaria no. 1:466', Boletim Oficial da Colónia de Timor 15:135, 9-4-1949.
} 


\section{Penfoei vs Baucau}

While the Dutch and the Portuguese were concerned with settling matters from the recent past, they also had their eyes on the future. Timor had been a vital link in aviation routes to Australia from the earliest days because of the relatively short distance over water to Darwin in the Northern Territory. The first scheduled service began in the mid 1930s, when Qantas Empire Airways operated an Australia-Britain route that used the Penfoei airfield at Koepang as a stopover between Darwin and Lombok. The service had been inaugurated to carry mail, but always carried passengers as well. The passenger service proved popular and a flying-boat service was added on the same route. In January 1941, at the request of the Australian government, Qantas also began a fortnightly flying-boat service to Dili (Stackhouse 1995:48-82). All AustraliaTimor services came to a halt with the beginning of the Pacific War.

In the early post-war years, Dutch aircraft travelling from Australia to Java also used Penfoei as a staging post. It was known that the Portuguese were planning a modern airfield in their territory and this may have spurred on the Dutch to improve their own facilities. In May 1947, Resident Schuller travelled to Portuguese Timor at the invitation of Governor Ruas to attend the opening of the new airfield at Baucau. Schuller noted that the airfield still needed hangars and other buildings, but that it was clearly designed as an international airport and rival to Penfoei. Plans had already been made, however, for the existing Penfoei runway to be lengthened and a new one built as well. Schuller reported that from 1 April 1948, Penfoei would be officially classed as an international airport, provided that all the improvements had been completed on time. ${ }^{62}$

In his August-September 1947 reports, Schuller noted that flights from Australia to Koepang had been disrupted, but that a service using Australian aircraft was being maintained for the Darwin-Dili route. From Dili, the Portuguese had established a weekly flight to Koepang, which stopped on its way at Oecussi, but also at Atamboea in Dutch territory. This service was utilized by passengers from Australia for Koepang, but was also used by members of the Dutch administration to travel to Atamboea. ${ }^{63}$ The service existed from at least

\footnotetext{
62 No. viII: Verslag van den Resident van Timor en Onderhoorigheden over de maand April 1947, 3-5-1947; No. IX-X: Politiek en economisch verslag van den Resident van Timor en Onderhoorigheden over Mei 1947, 2-6-1947, NA, Algemene Secretarie 3259.

63 Politiek verslag. Residentie Timor en Onderhoorigheden. Maand: Augustus 1947, 5-9-1947; Politiek Verslag. Residentie Timor en Onderhoorigheden. Maand: September 1947, NA, Algemene Secretarie 3259.
} 
as early as January 1947, when a passenger and cargo fare schedule appeared in the Portuguese government gazette. ${ }^{64}$ In October and November 1947, Schuller travelled from Koepang to Dili with the Portuguese air service and then flew on to Baucau and other parts of the territory. During his stay Schuller was told by Ruas that it was expected that from 1 January 1948 Constellation aircraft (fourengine Lockheed 749s) on the Darwin-Singapore-Hong Kong route would stop over in Baucau. As the airfield improvements at Koepang had stalled, Schuller considered this news to mean that the chance of Penfoei becoming an international airport had been lost. ${ }^{65}$

By March 1948, the runway extension at Penfoei had still not begun, but neither had the international flights to Baucau, although plans for a SydneyDarwin-Baucau-Shanghai-Hong Kong route were said to be 'getting stronger' and a radio station allowing contact with Lisbon and Sydney was due to begin operating by May. ${ }^{66}$ While more seemed to be happening in Baucau than at Penfoei, a measure of scepticism about Portuguese plans was evident in Dutch reports from at least September 1947, when it was noted that the projected Portuguese airline to replace Australian aeroplanes on the Darwin-Dili route did not yet exist. ${ }^{67}$ In March 1948, Schuller reported that the Portuguese company Transportes Aéreos de Timor (ТАT) was soon expected to start flying Douglas DC3 or Lockheed Hudson aircraft, but by June Schuller seemed jubilant when he declared: 'In the meantime, the great plans for the TAT to open an international airline with $\mathrm{DC}_{3}$ s or other large machines is not so noticeable!'68

In January 1949, Resident Verhoef noted that the fortnightly Darwin-Dili service was being maintained with Royal Australian Air Force aeroplanes for the convenience of the Australian consul. Otherwise, nothing had come of the plans to accept international air traffic at Baucau; there were no ground services and no refuelling facilities and the two British radio operators would be leaving shortly. Verhoef commented that if the long-delayed extensions at Pen-

\footnotetext{
64 'Circular', Boletim Oficial da Colónia de Timor 1:2, 4-1-1947.

65 Politiek verslag. Residentie Timor en Onderhoorigheden. Maand: October/November 1947, 15-12-1947, NA, Algemene Secretarie 3259.

66 Politiek verslag. Residentie Timor en Onderhoorigheden. Maand: Januari/Maart 1948, 154-1948, NA, Algemene Secretarie 326o.

67 Politiek verslag. Residentie Timor en Onderhoorigheden. Maand: September 1947, NA, Algemene Secretarie 3259 .

68 Politiek verslag. Residentie Timor en Onderhoorigheden. Maand: Januari/Maart 1948, 154-1948; Politiek verslag. Residentie Timor en Onderhoorigheden. Maand: April/Juni 1948, 18-6-1948, NA, Algemene Secretarie 326o.
} 
foei were made effective in a short time it would be able to offer a better service for international air connections than Baucau. ${ }^{69}$ It was not to be, however, and neither Penfoei nor Baucau were to operate as genuine international airports in the near future. Part of the problem was that aircraft used for flying to and from Australia in the post-war era could fly far greater distances without refuelling than the pre-war models; Qantas flying-boats on the Australia-Britain route could fly Darwin-Soerabaja (Surabaya) non-stop, ${ }^{70}$ while the Constellations put into service from 1947 could fly Darwin-Singapore direct (Stackhouse 1995:96-102; Clune 1949:12-3). There was no need and apparently no desire to stop at either Penfoei or Baucau.

\section{The Portuguese-Dutch Relationship: 'As Good As In Old Times'}

Despite the existence of some competition, the Portuguese-Dutch relationship was friendly and supportive. In his September 1947 report Schuller stated that relations were 'as good as in old times', with visiting officials from both sides receiving excellent hospitality. ${ }^{71}$ In March 1948 , the relationship was still said to be of a good nature, with each side sharing information and giving all possible assistance. ${ }^{72}$ Shortages of goods were common in Timor in the immediate postwar years, but both sides were willing to extend a helping hand when needed. For example, destruction caused by Allied bombing was widespread on both sides of the border. The number of bomb-damaged buildings in Koepang led Schuller in February 1947 to refer to the West Timor capital as a 'dead city'. ${ }^{73}$ Repairs and any new structures had to be made with whatever was at hand, resulting in Schuller describing Koepang as a 'coconut emergency town. ${ }^{74}$ Governor Ruas saw the destruction firsthand during a tour of Kefamenanoe

69 Politiek verslag. Residentie Timor en Onderhoorigheden. Tijdvak: Juli t/m Januari 1949, 27-1-1949, NA, Algemene Secretarie 3260.

70 The Short Empire flying-boats used by Qantas needed no airfield, only a mooring buoy at an appropriate lake or seaport.

71 Politiek verslag. Residentie Timor en Onderhoorigheden. Maand: September 1947, NA, Algemene Secretarie 3259 .

72 Politiek verslag. Residentie Timor en Onderhoorigheden. Maand: Januari/Maart 1948, 154-1948, NA, Algemene Secretarie 3260.

73 No. IV: Verslag van den Resident van Timor en Onderhoorigheden over Februari 1947, NA, Algemene Secretarie 3259 .

74 No. XIV: Verslag van den Resident van Timor en Onderhoorigheden over de maand Juli 1947, 10-8-1947, NA, Algemene Secretarie 3259. 
(Kefamenanu), SoE, and Koepang in May 1947. At Kefamenanoe, Ruas was shown the bullet-riddled Catholic church and promised to help with its repair, which he did later by sending 70 sheets of asbestos. Schuller was appreciative, but commented wistfully, 'One imagines that in Dilly [sic] there must be an enormous supply of building materials! ${ }^{75}$ In November 1947, Schuller learnt that the case was quite different when he visited Portuguese Timor as the guest of Ruas and travelled throughout the territory. The 'very extreme destruction', he reported, was 'most striking.7 ${ }^{76}$ The fact was that Ruas had as much of a problem getting materials as Schuller, so his help in repairing the church had been a generous act.

Portuguese and Dutch officials had also been willing to help each other in matters such as the return of escaped prisoners and fugitive criminals, including Japanese war criminals. Members of the Dutch administration were able to take advantage of a Portuguese Dili-Atamboea-Oecussi-Koepang air service, whereas people from Portuguese Timor benefitted from a connection with Dili made by a ship belonging to the Dutch KPM line, linking them with Koepang and other parts of the Indies. Another example of a willingness to help was the case in September 1947 of a Dutch government doctor providing his Portuguese colleague with a supply of penicillin, which would not be replaced until the next consignment arrived in Dili. ${ }^{77}$ There were also numerous cases of officials from both sides being invited by their colleagues across the border to join in social and cultural pursuits, such as the Dutch controleur of North Central Timor being invited to join a hunting party in Oecussi, or Governor Ruas being invited to Koepang by Resident Schuller to view a travelling exhibition of Balinese and other East Indonesian art. ${ }^{78}$

75 No. IX-X: Politiek en economisch verslag van den Resident van Timor en Onderhoorigheden over Mei 1947, 2-6-1947; Politiek verslag. Residentie Timor en Onderhoorigheden. Maand: Augustus 1947, 5-9-1947, NA, Algemene Secretarie 3259.

76 Politiek verslag. Residentie Timor en Onderhoorigheden. Maand: October/November 1947, 15-12-1947, NA, Algemene Secretarie 3259.

77 Politiek verslag. Residentie Timor en Onderhoorigheden. Maand: September 1947, NA, Algemene Secretarie 3259 .

78 Politiek verslag. Residentie Timor en Onderhoorigheden. Maand: September 1947; Politiek verslag. Residentie Timor en Onderhoorigheden. Maand: October/November 1947, 15-121947, NA, Algemene Secretarie 3259. 


\section{Portuguese and Dutch Concerns about the Indonesian Republic}

In the pre-war period, access to formal education and opportunities to participate in local politics and administration were vastly different for the people on either side of the border. In Dutch Timor several political organizations appeared in the 1920s, inspired by the nascent nationalist movement in Java. The political scene was also altered by the local publication of several Malaylanguage newspapers. Meanwhile, in Portuguese Timor there were no local political organizations and virtually no press, a situation that continued into the 1950s-196os. State and church schools operated on both sides of the border, but in West Timor there were both Protestant and Catholic schools and several schools run by private organizations (Farram 2009:108-32; Kammen 2016:99, 113). There was also greater opportunity in Dutch Timor for employment in the local administration..$^{79}$ These factors played a role in Timorese responses to political developments after the war.

Support for the newly declared Republic of Indonesia was seen in West Timor from the earliest days after the war. That support continued to grow, although opposition to the Dutch in Timor was mild compared to that in Java and Sumatra. An extension of political rights to the inhabitants of the Indies was Dutch post-war policy, but it came to be seen as a method for containing the Republic through the creation of semi-autonomous states in areas deemed to be pro-Dutch. The West Timorese received political representation at Makassar in the parliament of Negara Indonesia Timur (NIT, State of East Indonesia). The new system saw some Dutch officials replaced by Indonesians, but senior positions, such as resident and department head, remained in Dutch hands. Nevertheless, there was a decentralization of authority and this created some ambiguity. Thus, in May 1947, when the Australian consul at Dili, Eaton, visited West Timor, he was told by Schuller that he was not happy with the situation where he was a representative of the Dutch government, but also an advisor to the Indonesians. This meant he had to obey the orders of the NIT government in Makassar and the Netherlands Indies government in Batavia. Schuller said he would be glad when it was time for him to leave. Eaton heard similar complaints from other Dutch officials. ${ }^{80}$

79 It should be noted that the educated elite in Dutch Timor who benefitted from these conditions consisted mainly of Rotenese, Sabunese, and Kisarese, rather than native Timorese; Farram 2009:108.

8o No. 63: Eaton, Consul, to Secretary, Department of External Affairs, 12-5-1947, NAA Canberra, A1838, TS400/1/9/1/1. 
The Portuguese had misgivings about their neighbour extending democratic rights to the West Timorese, but they were even more concerned about the Republic. In April 1947, Ruas informed Schuller that he wanted no contact between the people of the Netherlands Indies and the inhabitants of Ataúro. Ruas gave as his reason that the people of Liran, the Netherlands Indies' island closest to Ataúro, were trying to spread 'Indonesian propaganda' in his territory. ${ }^{81}$ Given the isolation of the small population on the tiny island of Liran, one wonders just what sort of 'Indonesian propaganda' they may have possessed in the first place.

In a September 1947 report Schuller suggested that the Portuguese should not be concerned about 'extremist Javanese propaganda' entering their territory, as no Malay (that is, Indonesian) was spoken there: it was not taught in schools, no one subscribed to Malay-language newspapers, and any Malay radio propaganda would be ineffectual. Moreover, claimed Schuller, matters such as nationalism, democracy, and self-determination were unknown in Portuguese Timor. ${ }^{82}$ Despite Schuller's claims, Australia's representative at The Hague, Keith Officer, reported to Canberra a month later that he had learnt from a 'well-informed' source that the Dutch government had approached the Portuguese seeking assistance to prevent anti-Dutch propaganda entering its territory on Timor from across the border. The discussions concerned cooperation between local Dutch and Portuguese intelligence services. The Portuguese agreed readily out of fear of repercussions in their territory and suggested a combined Portuguese-Dutch police force take action if any trouble occurred on either side of the border. The Dutch considered this proposal to be too drastic. ${ }^{83}$

Harold White, the Australian consul at Dili who had replaced Eaton, was asked to comment on Officer's report and replied that in a discussion he had with Governor Ruas on 12 November, the latter denied the existence of any nationalist aspirations in Portuguese Timor. Ruas said he did not doubt the loyalty of the Timorese to the Portuguese and quoted the fact that all taxes had been collected from the border districts without resistance to support his case. Problems on the other side of the border, said Ruas, were due to the 'natives' there becoming 'imbued with the spirit of "democracy"'. According to the governor, that attitude had not affected the Portuguese Timorese, who

81 No. VIII: Verslag van den Resident van Timor en Onderhoorigheden over de maand April 1947, 3-5-1947, NA, Algemene Secretarie 3259.

82 Politiek verslag. Residentie Timor en Onderhoorigheden. Maand: Augustus 1947, 5-9-1947, NA, Algemene Secretarie 3259 .

83 Officer to Evatt, Ministerial Despatch Hag 26/47, The Hague, 8-10-1947, in Dorling 1994:348. 
were hostile to their counterparts across the border and had even asked for arms to use against them if necessary. Of course, said Ruas, arms would not be given. ${ }^{84}$

Ruas's claims and statements shifted from one pole to the other, but this may have reflected the different audiences he was addressing. Certainly, it seems that when the Dutch and Portuguese talked to each other there was little reluctance to discuss their fears of losing their colonial possessions. The Dutch found that their position in the Indies was far from secure. They had considered the Indonesian Republic to be of little account, but due to pressure from the U K, the USA, and others they had been forced to accept the Republic's right to exist; they tried, though, to contain its power and influence. Finally, claiming that the Republic did not exercise sufficient authority to maintain security, the Dutch launched a 'police action' at midnight on 20 July 1947, attacking Republican territory in Java and Sumatra. This resulted in the case being brought before the Un Security Council, where the Republic received support from various nations, including Australia. The story of the Republic's struggle to attain full independence and the Dutch efforts to limit it has been described at length elsewhere. ${ }^{85}$ Here it is sufficient to note that while the Dutch appear to have considered Portuguese colonialism as practised on Timor to be an outdated model, they were happy to elicit Portugal's support to help them continue to practise their own version in their half of the island and elsewhere in Indonesia.

On 6 September 1947, H.F.L.K. van Vredenburch, head of Politieke Zaken (Netherlands Directorate of Political Affairs), was visited by Portuguese chargé d' affaires, Mr Reymao. Van Vredenburch told Reymao how the Security Council was limiting the Netherlands' ability to deal with the situation in Indonesia. According to Van Vredenburch, Reymao realized that a worsening Dutch position in Indonesia could have consequences for Portuguese Timor, so he asked how he could help. Van Vredenburch requested that Portugal inform Brazil of the situation with a view that Brazil's UN representatives would not make the Dutch position any worse. Meanwhile, the Dutch attempted to influence Colombia through Curaçao, a part of the Netherlands Antilles. ${ }^{86}$ What effect the appeal to Brazil may have had is unclear, but the approach to Colombia would seem a failure, as during its term in the Security Council in 1947 it consistently supported the Indonesian Republic and opposed the Netherlands.

84 White to Burton, Memorandum 151, Dili, 26-11-1947, in Dorling 1994:421-2.

85 See, for example, George 1980, which also examines Australia's role.

86 Aantekening van de chef directie politieke zaken van het ministerie van buitenlandse zaken (Van Vredenburch), 8-9-1947, in Drooglever and Schouten 1983:56. 
The Netherlands continued to be assured of Portugal's support, but Portugal was limited in what it could do, as it was not a UN member at the time. In December 1948, the Dutch launched their second 'police action' against the Republic. The following month, Dutch foreign minister D.U. Stikker informed his cabinet colleagues of the reactions of various countries. Regarding Portugal, Stikker said that there was understanding and great sympathy for the Netherlands' efforts to neutralize Republican opposition in Indonesia. Stikker also told his colleagues how the press was dealing with the issue in each place he mentioned. In Portugal, he said, the press did not have its own version of events, an attitude enforced by a government that had difficulties in its own Asian colonies. ${ }^{87}$

\section{The Dutch Depart from Timor, the Portuguese Remain}

The first Dutch 'police action' against the Republic in 1947 was condemned by prominent countries, including ones otherwise sympathetic to the Netherlands, such as the UK and the USA. One result was the creation of the UN Good Offices Committee, charged with seeking a resolution of the dispute between the Netherlands and the Republic. The second 'police action' in 1948 led to further pressure for a solution to be found, and even the leaders of the NIT turned against their Dutch mentors. Finally, the Dutch conceded they were no longer welcome in the archipelago and prepared to hand sovereignty over to an independent Indonesia on 27 December 1949.

On 20 October 1949, ex-resident Verhoef wrote his last report for West Timor. Verhoef noted that the residency of Timor had ceased to exist on 1 October 1949 and all administrative functions had been handed over to local authorities. This transfer of power was marked by several public ceremonies. Commenting on one event that took place in Koepang, Verhoef told how formalities began with school children singing the new national anthem, 'Indonesia Raja' (Indonesia Raya). Meanwhile, the Dutch anthem 'Het Wilhemus' was not performed. This, said Verhoef, 'left a disagreeable impression' ${ }^{88}$ Like Schuller before him, Verhoef may have been glad to be leaving.

87 Minister van buitenlandse zaken (Stikker) aan de leden van de ministeraad en de vertegenwoordigers van Nederland in het buitenland, 14-1-1949, in Drooglever and Schouten 1992:30-8.

88 No. XI: Politiek verslag van de Residentie Timor Archipel over de maand September 1949, 20-10-1949, NA, Algemene Secretarie 3260. 
Portugal, meanwhile, did not need to deal with any form of nationalist movement in Portuguese Timor in the immediate post-war years, and there is no sign that any Portuguese Timorese were even aware of what was happening in the political sphere across the border or elsewhere in the Indies. At the same time, Portugal was largely immune from international criticism of its colonial system due to guarantees given by the UK and the USA to respect Portugal's colonial possessions after the war as a condition of their military use of the Azores (Gunn 2011:9).

\section{Conclusion}

In many respects the Portuguese-Dutch relationship on Timor continued to follow a pattern in the post-Second World War period similar to the one that existed before. Most problems concerned Timorese involvement in activities such as livestock theft, unauthorized immigration, and illegal killings. The Portuguese and the Dutch generally managed to deal with such cases in an amicable manner. The two powers did disagree on some issues, such as how to engage their subject populations, while their post-war development efforts gave the relationship a competitive edge. But post-war innovations such as the support granted to independence movements by other nations gave the Portuguese and the Dutch a measure of mutual identification that had previously been lacking. The success of the Indonesian independence movement resulted in the Dutch relinquishing all power in Timor. Various factors allowed the Portuguese to remain in control for much longer and the East Timorese had a long wait for their own independence—but that is another story.

\section{References}

\section{Unpublished Sources}

Australian War Memorial, Canberra (AWM)

AWM54, 773/4/14, Surrender of Japanese forces on Timor.

Nationaal Archief, The Hague (NA)

Algemene Secretarie 3259, Politieke en economische verslagen betreffende de residentie Timor en Onderhorigheden, uitgebracht door de resident in Kupang; 1946 okt-1947 dec.

Algemene Secretarie 3260, Politieke en economische verslagen betreffende de residentie Timor en Onderhorigheden, uitgebracht door de resident in Kupang; 1948 jan-1949 sep. 


\section{National Archives of Australia, Canberra (NAA Canberra)}

A981, тім P 9, Timor (Portuguese), Report by C.H. Archer (including movements by Archer).

A1838, 376/1/1, Portuguese Timor-General information-Papers \& statistics.

A1838, 377/1/3 Part 1, Portuguese Timor-Reports, despatches from Australian Consul. A1838, 377/1/3 Part 2, Portuguese Timor-Reports, despatches from Australian Consul. A1838, 3038/7/1 Part 1, Portuguese Timor-External relations-Foreign policy-

Including UN interests and other countries' assessments. A1838, TS400/1/9/1/1, East Indies-Dutch Timor-General information. A5954, 564/6, Japanese surrender-Military aspects. Re-occupation of Timor. A5954, 2269/4, South East Asia. Timor (from 1946).

National Archives of Australia, Melbourne (NAA Melbourne) MP742/1, 336/1/973, War Crimes_-Timor-(Murder, Fitzallen and West).

\section{Published Sources}

Boxer, C.R. (1947). The Topasses of Timor. Amsterdam: Indisch Instituut.

Bretes, Maria da Graça (1989). Timor-Entre invasores (1941-1945). Lisbon: Livros Horizonte.

Carvalho, Manuel de Abreu Ferreira de (1947). Relatorio dos acontecimentos de Timor. Lisbon: Imprensa Nacional.

Chamberlain, Ernest (2005). Faltering steps: Independence movements in East Timor in the 1950s and 196os. Point Lonsdale. [Self-published.]

Clune, Frank (1949). High-ho to London. Incidents and interviews on a leisurely journey by air from Australia to Britain. Sydney and London: Angus and Robertson.

Cribb, Robert (1992). Historical dictionary of Indonesia. Meutchen, New Jersey, and London: Scarecrow Press. [Asian Historical Dictionaries 9.]

Dorling, Philip (ed.) (1994). Diplomasi: Australia and Indonesia's independence. Documents 1947. Canberra: Australian Government Publishing Service.

Drooglever, P.J. and M.J.B. Schouten (eds) (1983). Officiële bescheiden betreffende de Nederlands-Indonesische betrekkingen 1945-1950. Vol. 11. '1 September-25 November 1947', 's-Gravenhage: Nijhoff.

Drooglever, P.J. and M.J.B. Schouten (eds) (1992). Officiële bescheiden betreffende de Nederlands-Indonesische betrekkingen 1945-1950. Vol. 17. '13 januari 1949-28 februari 1949', 's-Gravenhage: Nijhoff.

Farram, Steven (2009). A political history of West Timor, 1901-1967. Köln: LAP.

Friedberg, Claudine (1980). 'Boiled woman and broiled man: Myths and agricultural rituals of the Bunaq of Central Timor', in: James Fox (ed.), The flow of live: Essays on eastern Indonesia, pp. 267-365. Cambridge, MA and London, England: Harvard University Press. 
George, Margaret (1980). Australia and the Indonesian Revolution. Carlton: Melbourne University Press and the Australian Institute of International Affairs.

Gill, Rob (1995). 'The aftermath of war (Japanese soldiers on trial in Darwin)', Northern Perspective 18-2:95-100.

Gunn, Geoffrey C. (1999). Timor Loro Sae: 500 years. Macau: Livros do Oriente.

Gunn, Geoffrey C. (2011). Historical dictionary of East Timor. Lanham, Toronto, Plymouth, Uk: Scarecrow Press. [Historical Dictionaries of Asia, Oceania and the Middle East 78.]

Hägerdal, Hans (2012). Lords of the land, lords of the sea. Conflict and adaptation in early colonial Timor, 1600-180o. Leiden: KITLV Press.

Hudson, W.J. and Wendy May (eds) (1989). Documents on Australian foreign policy, 193749. Vol. 8: 1945. Canberra: Australian Government Publishing Service.

Kammen, Douglas (2016). Three centuries of conflict in East Timor. Singapore: NUs Press.

Kehi, Balthasar and Lisa Palmer (2012). 'Hamatak halirin. The cosmological and socioecological roles of water in Koba Lima, Timor', Bijdragen tot de Taal-, Land- en Volkenkunde (BKI) 168:445-71.

Ormeling, F.J. (1956). The Timor problem: A geographical interpretation of an underdeveloped island. Groningen/Djakarta: Wolters; 's-Gravenhage: Nijhoff.

Shepherd, Christopher J. and Andrew McWilliam (2013). 'Cultivating plantations and subjects in East Timor: A genealogy', BKI 169:326-61.

Shepherd, Christopher (2014). Development and environmental politics unmasked. Authority, participation and equity in East Timor. London and New York: Routledge.

Stackhouse, John (1995). ... from the dawn of aviation. The Qantas story, 1920-1995. Double Bay: Focus Publishing.

Tarling, Nicholas (2013). Britain and Portuguese Timor, 1941-1976. Clayton: Monash University Publishing.

Taylor, John G. (1991). Indonesia's forgotten war: The hidden history of East Timor. Leichhardt: Pluto Press.

Turner, Michele (1992). Telling East Timor: Personal testimonies 1942-1992. Kensington: New South Wales University Press.

Versluys, J.D.N. (1949-1950). 'Maatschappelijke vernieuwing op Timor?', Indonesië 3:130-50, 201-24.

Wal, S.L. van der (ed.) (1973). Officiële bescheiden betreffende de Nederlands-Indonesische betrekkingen 1945-1950. Vol. 3. '1 jan-30 maart 1946', 's-Gravenhage: Nijhoff.

Wal, S.L. van der (ed.) (1979). Officiële bescheiden betreffende de Nederlands-Indonesische betrekkingen 1945-1950. Vol. 8. '21 maart-20 mei 1947', 's-Gravenhage: Nijhoff. 